Article

\title{
An Assessment of the Effects of Applying Ash from the Thermal Disposal of Sewage Sludge for Fertilizing Energy Plants Using the Example of Giant Miscanthus (Miscanthus sinensis giganteus)
}

\author{
Sławomir Rybka * ${ }^{(D)}$ and Krzysztof Tereszkiewicz
}

check for updates

Citation: Rybka, S.; Tereszkiewicz, K. An Assessment of the Effects of Applying Ash from the Thermal Disposal of Sewage Sludge for Fertilizing Energy Plants Using the Example of Giant Miscanthus (Miscanthus sinensis giganteus). Sustainability 2021, 13, 12306. https://doi.org/10.3390/ su132112306

Academic Editor: Marc A. Rosen

Received: 24 July 2021

Accepted: 1 November 2021

Published: 8 November 2021

Publisher's Note: MDPI stays neutral with regard to jurisdictional claims in published maps and institutional affiliations.

Copyright: (c) 2021 by the authors. Licensee MDPI, Basel, Switzerland. This article is an open access article distributed under the terms and conditions of the Creative Commons Attribution (CC BY) license (https:// creativecommons.org/licenses/by/ $4.0 /)$.
The Faculty of Management, Department of Computer Engineering in Management, Rzeszow University of Technology, 35-959 Rzeszow, Poland; kteresz@prz.edu.pl

* Correspondence: s.rybka@prz.edu.pl

\begin{abstract}
The aim of the research was to determine the possibility of using ash from the thermal utilization of municipal sewage sludge as a fertilizer in the cultivation of giant miscanthus (Miscanthus sinensis giganteus) for energy purposes. An attempt was also made to determine the optimal level of fertilization with ash from the thermal utilization of municipal sewage sludge in the commodity cultivation of miscanthus. It was assumed that the ash produced after thermal utilization of municipal sewage sludge could replace conventional mineral fertilizers. To prove the thesis, laboratory experiments of the miscanthus cultivation miscanthus were carried out. The results allowed to determine the optimal fertilization dose for miscanthus to be used in the next stage of the field research. Miscanthus does not pose a succession threat due to the method of reproduction in central Europe; therefore, its cultivation may remain under control. The research showed that for fertilization of miscanthus $\times$ giganteus crops, the ashes from thermal utilization of municipal sewage sludge could be used effectively. In experimental crops, it was shown that the optimal level of miscanthus fertilization in terms of yield was $8.32 \mathrm{~g}$ of ash per pot and $0.1 \mathrm{~g}$ of nitrogen per pot. As a result of laboratory tests, based on biometric features, the most favorable dose of ash and nitrogen fertilization from thermal utilization of municipal sewage sludge for use in field conditions was selected. The dose amounted to $3.7 \mathrm{t}$ of ash $\cdot \mathrm{ha}^{-1}$ and $45 \mathrm{~kg}$ of nitrogen $\cdot \mathrm{ha}^{-1}$. In order to reduce the costs of cultivation, it was possible to abandon the use of nitrogen fertilizers since their omission did not cause a significant drop in yield. It is necessary to continue research in the field in order to confirm the correctness of the results obtained from laboratory tests.
\end{abstract}

Keywords: sustainable development; environmental protection; thermal utilization of municipal sewage sludge; fertilization of energy crops; miscanthus

\section{Introduction}

The approach currently presented by the European Commission assumes a circular economy model. Thus, it gives a clear message to entrepreneurs that the priority and leading direction of the development of the European Union in the near future will be the use of all available methods in order to implement the principle of sustainable development to economy. It is assumed that the efficiency of systems supervising the use, recovery, and management of resources will be improved by reusing waste. Such an action will bring measurable economic and environmental benefits. According to the assumptions of the circular economy system, the development of products should be carried out in such a way that after their use or the end of their use, they do not constitute waste materials, but are instead raw materials with recycling possibilities. The model of management mentioned is currently being implemented in many areas of the economy. It finds a place in innovative waste management systems. It is assumed that the circular economy will 
potentially stimulate Europe economically, which in turn will contribute to the creation of many new jobs, as well as preserve valuable non-renewable natural resources [1-6].

The recycling of sewage sludge is an important element of the strategy for a circular raw material economy. Currently, sewage sludge is treated with the greatest share by means of composting, fertilization, and land reclamation [7-9].

The aim of the research was to determine the possibility of using ash from the thermal utilization of municipal sewage sludge as a fertilizer in the cultivation of giant miscanthus (Miscanthus sinensis giganteus), for energy purposes. An attempt was also made to determine the optimal level of fertilization with ash from the thermal utilization of municipal sewage sludge in commodity cultivation of miscanthus.

In most European Union countries, the main directions of municipal sewage sludge management are composting, fertilization, and land reclamation. In some countries (Poland, Cyprus, Lithuania), a significant share of this type of waste is still only landfilled without recycling it [10].

Currently, there is a constant increase in the amount of sewage sludge produced. It is related to the development of civilization and the expansion of the sewage network in developed countries of Europe. At the same time, the legal requirements that allow sewage sludge to be deposited in landfills are being tightened. In Poland, according to the Regulation of the Minister of Economy of 16 July 2015 on the approval of waste for storage in landfills Journal of Laws of 2015, item 1277 municipal sewage sludge with a heat of combustion greater than $6 \mathrm{MJ} \cdot \mathrm{kg}^{1}$ dry weight, from 1 January 2016, cannot be stored in landfills. For instance, in Germany, the ban on the storage of municipal sewage sludge was introduced in 2005. In Germany, in 2013,54.6\% of municipal sewage sludge was subject to thermal treatment, while in Poland, it was only $10.6 \%$ [11,12].

According to Burzała, thermal utilization is an effective and economically justified method of municipal sewage sludge management [13]. Bien states that sewage sludge incineration will be one of the main directions of management in the near future [14]. Thermal utilization of municipal sewage sludge (TUoMSS) already dominates, e.g., in the Netherlands, Switzerland, and Germany [10]. The ash produced after the thermal treatment of municipal sewage sludge constitutes about $45 \%$ of the dry weight of the sludge subject to this process. The ash obtained in the combustion process is characterized by a high content of valuable macro- and microelements such as phosphorus, potassium, magnesium, calcium, and sulfur. After burning, the ash still requires landfilling, but it takes up much less space and does not emit odor compounds; hence, it is less harmful to the environment. In addition to storage, the ash can also be used in the production of building materials, including cement. It is used in the construction of road infrastructure, including the foundation of roads and highways and the construction of embankments [15]. The ash from TUoMSS can be used as a mineral fertilizer. The condition for this method of management is the combustion of pure biomass, which does not contain pollutants and waste, increasing its calorific value [16]. The ash from TUoMSS has a rich mineral composition; above all, it is characterized by a high content of phosphorus and potassium. There is information in the literature that the content of phosphorus and potassium in the ash from sewage sludge ranges from a few to a dozen or so percent [17]. According to Guedes et al., ash from TUoMSS contains $8.88 \%$ phosphorus [18]. The same research shows that this material may contain as much as 12.9 to $13.4 \%$ phosphorus. Researchers Pettersson et al. determine the content of phosphorus in ash from municipal sewage sludge in a range from $3.3 \%$ to $6.13 \%$ [19]. Taking into account the assumptions of the European Union regarding the need to reduce the consumption of natural phosphorus resources, research towards the agricultural use of phosphorus-rich ash from TUoMSS are in line with the current policy of the European Union. Numerous studies have been conducted around the world on the production of fertilizers from municipal sewage sludge. However, little attention is paid to developing ways to use TUoMSS ash as a mineral fertilizer [20].

Giant miscanthus (Miscanthus sinensis giganteus) grown for energy purposes was the test subject in the research. The plant was grown for straw for the production of solid fuels. 
Miscanthus is a perennial plant characterized by extensive underground rhizomes. The plant has a very stiff, hairy stem with high resistance to mechanical damage. Miscanthus also has long, flattened, lanceolate leaves. In the wild, it can reach up to $6 \mathrm{~m}$ in height. It is characterized by the $\mathrm{C}_{4}$ photosynthetic pathway, resulting in rapid growth. The cultivation of perennial grasses with the $C_{4}$ photosynthesis pathway is very effective in terms of the use of nutrients [21]. Miscanthus can be grown in poor-quality soils, including sandy, highly eroded, or polluted ones [22]. Growing miscanthus yields a great harvest that can limit premature crops. In addition, harvesting should be carried out without damaging the network of underground plant rhizomes, which reduces the yield in the next production cycle. There are opinions that miscanthus grown in Europe for energy purposes can spread and become an invasive weed. However, in the climate of Central Europe, miscanthus does not bloom and mature; hence, the risk of uncontrolled succession of the species is minimal [23].

\section{Materials and Methods}

The research aimed at determining a possibility of using ash which is the product of thermal utilization of municipal sewage sludge. The ash will be used as a fertilizer in the cultivation of Miscanthus sinensis giganteus, for energy purposes. An attempt was also made to determine the optimal level of fertilization with ash from the thermal utilization of municipal sewage sludge in commodity cultivation of miscanthus.

Miscanthus seedlings were purchased from a Polish supplier, Marian Pokrywka from Majdan Sieniawski. The seedlings were from 2-year-old plants. The material was delivered in the form of rhizomes. The experimental cultivation was established on April 15. Laboratory pot tests were carried out at the Faculty of Biology and Agriculture of the University of Rzeszów in Rzeszów. The rhizomes were planted in $4.50 \mathrm{dm}^{3}$ pots. For the experimental cultivation, a substrate containing soil and ash from TUoMSS as well as nitrogen fertilizer were used. The composition of the substrate used in individual pots was compiled in accordance with the experiment system presented in Table 1. Before putting it into the pots, all the components of the substrate were thoroughly mixed, and then the same amounts of soil with fertilizing components were weighed into individual pots. In the experiment, ash from the thermal utilization of municipal sewage sludge from the Thermal Sewage Sludge Treatment Station of Miejskie Przedsiębiorstwo Wodociagów i Kanalizacji Spółka Akcyjna (Municipal Water and Sewerage Company, Krakow, Poland) in Kraków was used. The soil for pot tests was taken from the experimental field of the University of Rzeszów. The soil's pH, salinity, and the content of assimilable forms of macronutrients and selected metals were determined. Ammonium nitrate Pulan $34 \mathrm{~N}$ was used as the nitrogen source.

Table 1. Experimental model with the levels of fertilization applied.

\begin{tabular}{llll}
\hline \multicolumn{4}{c}{ First replication } \\
\hline A1N1 & A2N1 & A3N1 & A4N1 \\
\hline A1N2 & A2N2 & A3N2 & A4N2 \\
\hline A1N3 & A2N3 & A3N3 & A4N3 \\
\hline \multicolumn{5}{c}{ Second replication } \\
\hline A1N1 & A2N1 & A3N1 & A4N1 \\
\hline A1N2 & A2N2 & A3N2 & A4N2 \\
\hline A1N3 & A2N3 & A3N3 & A4N3 \\
\hline A1N2 & \multicolumn{2}{c}{ Third replication } & A4N2 \\
\hline A1N3 & A2N2 & A3N3 & A4N3 \\
\hline A1N1 & A2N3 & A3N3 & A4N1 \\
\hline
\end{tabular}

Source: own research. 
The research included 2 factors. There were 3 replications. Each pot was of $225 \mathrm{~cm}^{2}$ and its dimensions were $15 \mathrm{~cm} \times 15 \mathrm{~cm} \times 20 \mathrm{~cm}$. The tests of individual fertilization variants on miscanthus plants were carried out in order to verify the correctness of the selected doses of the ash from TUoMSS. The pot cultivation was carried out under a roof that let the light rays pass through. In addition, free access to sunlight was ensured. The optimum soil moisture was maintained at $70 \%$ of the field water capacity thanks to the drip irrigation system. During the vegetation period, the pots were weeded by hand as needed. Before harvesting, the biometric features of the experimental plants were measured. During the measurements, the maximum height of the stems, the thickness of the stems at a height of $15 \mathrm{~cm}$ from the ground, and the degree of branching were determined. Harvesting was carried out in the winter of January 9. Winter harvesting is characterized by a higher dry-matter content of the material harvested. The material from winter harvest has a higher concentration of cellulose. This dependence is related to the lower water content in plants in winter, which facilitates the mechanization of works and storage. The material harvested in winter is characterized by a better quality, associated with an increase in the calorific value [24]. The experimental plants were harvested by hand by means of garden shears.

The experimental model of a potted miscanthus $\times$ giganteus is presented below.

An experimental factor A-level of ash fertilization from TUoMSS. Four levels of fertilization with ash from TUoMSS were applied:

$\mathrm{A} 1-0 \mathrm{~g} \cdot \mathrm{pot}^{-1}, \mathrm{~A} 2-4.16 \mathrm{~g} \cdot \mathrm{pot}^{-1}, \mathrm{~A} 3-8.32 \mathrm{~g} \cdot \mathrm{pot}^{-1}, \mathrm{~A} 4-16.64 \mathrm{~g} \cdot \mathrm{pot}^{-1}$

The dose of ash from thermal utilization of municipal sewage sludge was applied to a $225 \mathrm{~cm}^{2}$ pot. Nitrogen fertilization was applied in the following nitrogen doses per pot with an area of $225 \mathrm{~cm}^{2}$ :

$\mathrm{N} 1-0 \mathrm{~g} \cdot \mathrm{pot}^{-1}, \mathrm{~N} 2-0.1 \mathrm{~g} \cdot \mathrm{pot}^{-1}, \mathrm{~N} 3-0.2 \mathrm{~g} \cdot \mathrm{pot}^{-1}$

A detailed plan of the experiment model presenting variants of the applied doses of fertilization is presented in Table 1.

Before setting up the pot experiment, the soil for pot cultivation was taken from the area intended for commodity cultivation. Soil samples were collected for laboratory tests using Egner's cane from 30 places on the field surface. The collective sample weighs $0.6 \mathrm{~kg}$. The soil was analyzed in terms of the total content of macronutrients: phosphorus, potassium, magnesium, calcium, and sulfur. The content of heavy metals (copper, nickel, zinc, sodium, lead, and cadmium) was also tested. The content of assimilable forms of macronutrients was determined. The content of available forms of phosphorus and potassium in the soil studied was determined by means of the Egner-Riehm method. This method was based on extraction with a buffered solution of calcium lactate and lactic acid. The $\mathrm{pH}$ of this mixture was 3.55 and the ratio of soil to solution $(\mathrm{m} / \mathrm{v})$ was $1: 10$. The analysis was carried out on the basis of the Polish standards [25-28]. The determination of the content of elements was carried out by means of the ICP-OES 6500 apparatus after prior mineralization of the material in the mixture of nitric (V) and chloric (VII) acids. The analyzer was equipped with Echelle optics with a CID semiconductor detector with an elemental spectrum in the range 166-847 $\mathrm{nm}$ and a resolution of $200 \mathrm{~nm}$. When analyzing the soil in terms of the magnesium content, the soil was extracted with a calcium chloride solution soil analysis. The soil extraction using a calcium chloride solution was performed. The analysis was carried out based on the Polish standard. The soil $\mathrm{pH}$ was determined by the potentiometric method in two variants $\left(\mathrm{pH}_{\mathrm{H} 2 \mathrm{O}}, \mathrm{pH}_{\mathrm{KCL}}\right)$.

The calorific value of miscanthus biomass from pot crops was determined by testing with the LECO AC500 calorimeter (Leco, Vouersweg, The Netherlands) based on the standard [29]. The LECO AC500 calorimeter was a device dedicated to determining the calorific value of organic and inorganic material, including biomass, waste, solid and liquid fuels, and food products. The LECO AC500 device determines the heat of combustion by burning the sample in an oxygen atmosphere. The combustion process was carried out in a classic calorimetric bomb submerged in water. The essence of the device's operation was to place the calorimetric bomb in water in such a way that the water jacket surrounded the measuring system on all sides. Such a system allowed to monitor the heat transfer 
in all directions. The temperature of the water surrounding the calorimetry bomb was measured by means of an electronic thermometer with an accuracy of $0.0001^{\circ}$. Maintaining the temperature of the casing at the appropriate level was achieved with the use of a cooler that was a part of the water system. The cooler was equipped with a fan with modulated revolutions, which helped maintain the set temperature of the cover. In the LECO AC500 calorimeter, there was a risk of a slight energy exchange between the reservoir surrounding the calorimeter vessel and the vessel itself. This trend was monitored in real time by the measurement system. If there was a possible change in the ambient temperature, the appropriate correction would be automatically included in the calculations. The LECO AC500 device continuously measured the temperature of the water surrounding the calorimetric bomb. Using an analog-to-digital converter, the input data were processed and then the data were saved in the device's memory. The water temperature difference between the beginning and the end of the measurement was processed by the software installed on the computer. The result of this operation was the final result.

The statistical analysis of the results was carried out using a two-way analysis of variance in our design. The number of replications was $n=3$. The values of $\mathrm{NIR}_{0.05}$ were presented in the tables of average results, specifying the following effects of $\mathrm{P}$-ash fertilization with TUoMSS, N-nitrogen fertilization, and interactions between the tested $\mathrm{N}^{*} \mathrm{P}$ factors. The calculations were made using Tukey's test.

The doses for the purposes of further field research were converted into units that can be used in field cultivation:

Factor P 1. Four levels of fertilization with ash from thermal utilization of sewage sludge: PI— 0 g. pot $^{-1}\left(0 \mathrm{t} \cdot \mathrm{ha}{ }^{-1}\right)$

PII-4.16 g.pot ${ }^{-1}\left(1.85 \mathrm{t} \cdot \mathrm{ha}^{-1}\right)$

PIII-8.32 g.pot ${ }^{-1}\left(3.7 \mathrm{t} \cdot \mathrm{ha}^{-1}\right)$

P IV-16.64 g. $\operatorname{pot}^{-1}\left(7.4 \mathrm{t} \cdot \mathrm{ha}^{-1}\right)$

Factor N 2. Nitrogen fertilization:

$\mathrm{A}-0 \mathrm{~g} \cdot \operatorname{pot}^{-1}\left(0 \mathrm{~kg} \cdot \mathrm{ha}^{-1}\right)$

B- $-0.1 \mathrm{~g} \cdot \operatorname{pot}^{-1}\left(45 \mathrm{~kg} \cdot \mathrm{ha}^{-1}\right)$

C $-0.2 \mathrm{~g} \cdot \operatorname{pot}^{-1}\left(90 \mathrm{~kg} \cdot \mathrm{ha}^{-1}\right)$

\section{Results}

Before starting the experiment, the soil and ash formed from TUoMSS used in the experiment were analyzed (Table 2). The analysis of soil and ash allowed the precise implementation of the model of the experiment.

Table 2. Characteristics of the soil used in the experiment.

\begin{tabular}{|c|c|c|c|c|c|c|}
\hline \multicolumn{7}{|c|}{ Soil $\mathrm{pH}$ and Salinity Used in the Experiment } \\
\hline \multicolumn{2}{|c|}{$\mathrm{pH}_{\mathrm{H} 2 \mathrm{O}}$} & \multicolumn{2}{|c|}{$\mathrm{pH}_{\mathrm{KCL}}$} & \multicolumn{3}{|c|}{$\begin{array}{l}\text { Soil Salinity } \\
{\left[\mathrm{Ds} \mathrm{m} \mathrm{m}^{-1}\right]}\end{array}$} \\
\hline \multicolumn{2}{|c|}{5.48} & \multicolumn{2}{|c|}{5.1} & \multicolumn{3}{|c|}{0.15} \\
\hline \multicolumn{7}{|c|}{ The content of assimilable forms of macronutrients in the soil used in the experiment } \\
\hline $\begin{array}{l}\text { Phosphorus } \\
\left(\mathrm{gP} \cdot \mathrm{kg}^{-1}\right)\end{array}$ & \multicolumn{2}{|c|}{$\begin{array}{l}\text { Potassium } \\
\left(\mathrm{gK} \cdot \mathrm{kg}^{-1}\right)\end{array}$} & \multicolumn{2}{|c|}{$\begin{array}{c}\text { Calcium } \\
\left(\mathrm{gCa} \cdot \mathrm{kg}^{-1}\right)\end{array}$} & \multicolumn{2}{|c|}{$\begin{array}{l}\text { Magnesium } \\
\left(\mathrm{gMg} \cdot \mathrm{kg}^{-1}\right)\end{array}$} \\
\hline 6.1 & \multicolumn{2}{|c|}{9.85} & \multicolumn{2}{|c|}{28.14} & \multicolumn{2}{|c|}{14.42} \\
\hline \multicolumn{7}{|c|}{ Total content of selected metals in the soil from the experiment } \\
\hline $\begin{array}{c}\text { Iron } \\
\left(\mathrm{mg} \cdot \mathrm{kg}^{-1} \mathrm{DW}\right)\end{array}$ & $\begin{array}{c}\text { Nickel } \\
\left(\mathrm{mg} \cdot \mathrm{kg}^{-1} \mathrm{DW}\right)\end{array}$ & $\begin{array}{c}\text { Copper } \\
\left(\mathrm{mg} \cdot \mathrm{kg}^{-1} \mathrm{DW}\right)\end{array}$ & $\begin{array}{c}\text { Chromium } \\
\left(\mathrm{mg} \cdot \mathrm{kg}^{-1} \mathrm{DW}\right)\end{array}$ & $\begin{array}{c}\text { Zinc } \\
\left(\mathrm{mg} \cdot \mathrm{kg}^{-1} \mathrm{DW}\right)\end{array}$ & $\begin{array}{c}\text { Cadmium } \\
\left(\mathrm{mg} \cdot \mathrm{kg}^{-1} \mathrm{DW}\right)\end{array}$ & $\begin{array}{c}\text { Manganese } \\
\left(\mathrm{mg} \cdot \mathrm{kg}^{-1} \mathrm{DW}\right)\end{array}$ \\
\hline 4265 & 14.6 & 9.2 & 28.4 & 10.6 & $<0.30$ & 394.6 \\
\hline
\end{tabular}


Before starting the experiment, the ash analysis from TUoMSS used in the experiment was performed. Chemical analysis of ashes from TUoMSS was carried out using the current national standards [18-21]. Table 3 presents the chemical characteristics of the ashes used in the pot experiment.

Table 3. Reaction and total content of selected elements in ashes from thermal utilization of municipal sewage sludge used in pot experiments.

\begin{tabular}{ccccccc}
\hline $\mathrm{pH}$ & $\begin{array}{c}\text { Nitrogen } \\
(\mathrm{g} / \mathrm{kg})\end{array}$ & $\begin{array}{c}\text { Phosphorus } \\
(\mathrm{g} / \mathrm{kg})\end{array}$ & $\begin{array}{c}\text { Potassium } \\
(\mathrm{g} / \mathrm{kg})\end{array}$ & $\begin{array}{c}\text { Calcium } \\
(\mathrm{g} / \mathrm{kg})\end{array}$ & $\begin{array}{c}\text { Magnesium } \\
(\mathrm{g} / \mathrm{kg})\end{array}$ & $\begin{array}{c}\text { Lead } \\
\left(\mathrm{mg} \cdot \mathrm{kg}^{-1}\right)\end{array}$ \\
\hline 9.2 & $<1.0$ & 48.6 & 21.6 & 7.7 & 1.9 & 36.42 \\
\hline & $\begin{array}{c}\text { Nickel } \\
\left(\mathrm{mg}^{\mathrm{kg}}{ }^{-1}\right)\end{array}$ & $\begin{array}{c}\text { Copper } \\
\left(\mathrm{mg} \cdot \mathrm{kg}^{-1}\right)\end{array}$ & $\begin{array}{c}\text { Chromium } \\
\left(\mathrm{mg} \cdot \mathrm{kg}^{-1}\right)\end{array}$ & \begin{tabular}{c}
$\mathrm{Zinc}_{\left(\mathrm{mg} \cdot \mathrm{kg}^{-1}\right)}$ \\
\cline { 2 - 7 }
\end{tabular} & $\begin{array}{c}\text { Cadmium } \\
\left(\mathrm{mg} \cdot \mathrm{kg}^{-1}\right)\end{array}$ & $\begin{array}{c}\text { Mercury } \\
\left(\mathrm{mg} \cdot \mathrm{kg}^{-1}\right)\end{array}$ \\
\hline
\end{tabular}

Source: own research

Table 4 shows the results of measuring the height of miscanthus stems depending on the experimental factors.

Table 4. Effect of fertilization with ash from thermal utilization of sewage sludge $(\mathrm{P})$ and nitrogen $(\mathrm{N})$ on the height of miscanthus stems $(\mathrm{cm})$.

\begin{tabular}{|c|c|c|c|c|c|}
\hline \multicolumn{2}{|l|}{ Factor } & \multicolumn{4}{|c|}{$\begin{array}{c}\text { Fertilization with Ash from Thermal Utilization of } \\
\text { Municipal Sewage Sludge }\left(g \cdot \operatorname{pot}^{-1}\right)\end{array}$} \\
\hline $\begin{array}{l}\text { Nitrogen Fertilization } \\
\left(\mathrm{g} \cdot \mathrm{pot}^{-1}\right)\end{array}$ & Repetition & A1-0 & $\mathrm{A} 2-4.16$ & $\mathrm{~A} 3-8.32$ & $\mathrm{~A} 4-16.64$ \\
\hline & I & 162 & 181 & 181 & 180 \\
\hline & II & 181 & 193 & 201 & 196 \\
\hline \multirow[t]{3}{*}{0} & III & 175 & 184 & 199 & 193 \\
\hline & I & 187 & 198 & 215 & 211 \\
\hline & II & 181 & 202 & 214 & 205 \\
\hline \multirow[t]{3}{*}{0.1} & III & 185 & 205 & 218 & 204 \\
\hline & I & 198 & 212 & 207 & 205 \\
\hline & II & 202 & 208 & 215 & 214 \\
\hline 0.2 & III & 204 & 212 & 212 & 209 \\
\hline $\mathrm{NIR}_{\alpha=0.05}$ & & & $=7.681 ; \mathrm{N}=$ & $22 ; \mathrm{N} / \mathrm{P}=1$ & \\
\hline
\end{tabular}

Source: own research. n.i.-a statistically insignificant difference.

The measurement of the diameter of shoots in Table 5 shows that the thickest shoots when fertilized with ash only were obtained with a dose of $8.32 \mathrm{~g} \cdot \mathrm{pot}^{-1}$; a further increase in the level of fertilization caused a decrease in the average value of this parameter. It is worth noting that the thickness of miscanthus stems was positively influenced by the introduction of nitrogen into the soil, but the obtained effects of nitrogen fertilization measured by the thickness of the shoots were unsatisfactory.

Table 6 shows the results of fertilization with the ash from thermal utilization of sewage sludge $(\mathrm{P})$ and nitrogen $(\mathrm{N})$ on the propagation of miscanthus (pcs.).

Table 7 shows the results of fertilization with the ash from thermal utilization of sewage sludge $(\mathrm{P})$ and nitrogen $(\mathrm{N})$ on the calorific value in the aboveground parts of miscanthus $\left(\mathrm{MJ} \cdot \mathrm{kg}^{-1}\right)$. 
Table 5. Effect of fertilization with ash from thermal utilization of sewage sludge $(\mathrm{P})$ and nitrogen $(\mathrm{N})$ on the diameter of miscanthus stems $(\mathrm{cm})$.

\begin{tabular}{|c|c|c|c|c|c|}
\hline \multicolumn{2}{|l|}{ Factor } & \multicolumn{4}{|c|}{$\begin{array}{l}\text { Fertilization with Ash from Thermal Utilization of } \\
\text { Municipal Sewage Sludge }\left(g \cdot \operatorname{pot}^{-1}\right)\end{array}$} \\
\hline Nitrogen Fertilization $\left(g \cdot\right.$ pot $^{-1}$ ) & Repetition & A1-0 & A2-4.16 & A3-8.32 & A4-16.64 \\
\hline & I & 0.88 & 1.10 & 1.10 & 1.10 \\
\hline & II & 1.10 & 1.15 & 1.20 & 1.00 \\
\hline \multirow[t]{3}{*}{0} & III & 1.05 & 1.10 & 1.15 & 1.05 \\
\hline & I & 1.20 & 1.20 & 1.25 & 1.20 \\
\hline & II & 1.10 & 1.15 & 1.20 & 1.15 \\
\hline \multirow[t]{3}{*}{0.1} & III & 1.15 & 1.20 & 1.15 & 1.20 \\
\hline & I & 1.25 & 1.30 & 1.25 & 1.25 \\
\hline & II & 1.20 & 1.25 & 1.35 & 1.20 \\
\hline 0.2 & III & 1.25 & 1.30 & 1.30 & 1.20 \\
\hline \multicolumn{2}{|l|}{$\mathrm{NIR}_{\alpha=0.05}$} & \multicolumn{4}{|c|}{$\mathrm{P}=0.066 ; \mathrm{N}=0.052 ; \mathrm{P} / \mathrm{N}=$ n.i. } \\
\hline
\end{tabular}

Source: own research. n.i.-a statistically insignificant difference.

Table 6. Effect of fertilization with ash from thermal utilization of sewage sludge $(\mathrm{P})$ and nitrogen (N) on the propagation of miscanthus (pcs.).

\begin{tabular}{|c|c|c|c|c|c|}
\hline \multicolumn{2}{|l|}{ Factor } & \multicolumn{4}{|c|}{$\begin{array}{l}\text { Fertilization with Ash from Thermal Utilization of } \\
\text { Municipal Sewage Sludge }\left(g \cdot \operatorname{pot}^{-1}\right)\end{array}$} \\
\hline Nitrogen Fertilization $\left(g \cdot \operatorname{pot}^{-1}\right.$ ) & Repetition & A1-0 & $\mathrm{A} 2-4.16$ & A3-8.32 & A4-16.64 \\
\hline & I & 5 & 7 & 8 & 7 \\
\hline & II & 6 & 6 & 7 & 8 \\
\hline \multirow[t]{3}{*}{0} & III & 5 & 7 & 7 & 7 \\
\hline & I & 8 & 8 & 9 & 8 \\
\hline & II & 7 & 8 & 8 & 8 \\
\hline \multirow[t]{3}{*}{0.1} & III & 7 & 9 & 9 & 9 \\
\hline & I & 7 & 8 & 9 & 9 \\
\hline & II & 8 & 8 & 9 & 9 \\
\hline 0.2 & III & 7 & 9 & 8 & 8 \\
\hline \multicolumn{2}{|l|}{$\mathrm{NIR}_{\alpha=0.05}$} & \multicolumn{4}{|c|}{$\mathrm{P}=0.751 ; \mathrm{N}=0.589 ; \mathrm{N} / \mathrm{P}=$ n.i. } \\
\hline
\end{tabular}

Source: own research n.i.--a statistically insignificant difference.

Table 7. Effect of fertilization with ash from thermal utilization of sewage sludge $(\mathrm{P})$ and nitrogen (N) on the calorific value in the aboveground parts of miscanthus $\left(\mathrm{MJ} \cdot \mathrm{kg}^{-1}\right)$.

\begin{tabular}{|c|c|c|c|c|c|}
\hline \multicolumn{2}{|l|}{ Factor } & \multicolumn{4}{|c|}{$\begin{array}{l}\text { Fertilization with Ash from Thermal Utilization of } \\
\text { Municipal Sewage Sludge }\left(g \cdot \operatorname{pot}^{-1}\right)\end{array}$} \\
\hline Nitrogen Fertilization $\left(\mathrm{g} \cdot \operatorname{pot}^{-1}\right)$ & Repetition & A1-0 & A2-4.16 & $\mathrm{A} 3-8.32$ & A4-16.64 \\
\hline & I & 17.20 & 17.41 & 17.46 & 17.40 \\
\hline & II & 17.17 & 17.35 & 17.48 & 17.36 \\
\hline \multirow[t]{3}{*}{0} & III & 17.40 & 17.36 & 17.42 & 17.32 \\
\hline & I & 17.70 & 17.32 & 17.82 & 17.46 \\
\hline & II & 17.72 & 17.36 & 17.64 & 17.42 \\
\hline \multirow[t]{3}{*}{0.1} & III & 17.76 & 17.33 & 17.58 & 17.47 \\
\hline & I & 17.94 & 17.62 & 17.71 & 17.62 \\
\hline & II & 17.84 & 17.58 & 17.64 & 17.68 \\
\hline 0.2 & III & 17.94 & 17.61 & 17.68 & 17.66 \\
\hline \multicolumn{2}{|l|}{$\mathrm{NIR}_{\alpha=0.05}$} & \multicolumn{4}{|c|}{$\mathrm{P}=0.078 ; \mathrm{N}=0.061 ; \mathrm{N} / \mathrm{P}=0.122$} \\
\hline
\end{tabular}

Source: own research. n.i.-a statistically insignificant difference.

\section{Discussion}

The results of the soil analyzes are presented in Table 2. Based on the chemical analysis of the soil, the agronomic category was established. It was decided that the soil 
used in the experiment was of the heavy type. In terms of agricultural suitability, the soil used belonged to class IV defective wheat complex. The soil was acidic (Table 3). The content of plant-available forms of potassium and phosphorus was low, while the content of plant-available forms of magnesium was high [30]. Assuming a pot experiment, the dose of the ash from TUoMSS, and the doses of nitrogen fertilizers, taking into account the content of phosphorus, potassium, calcium, and nitrogen in the ash from TUoMSS, and fertilization recommendations were established [31-33]. The $\mathrm{pH}$ value was also taken into account, as well as literature data showing that miscanthus can be grown at a much lower level of fertilization than, for example, maize [30]. In the experiment, the biochar additive was not used, based on previous studies that showed that its application in the amount of 8 or $25 \mathrm{t} \cdot \mathrm{ha}^{-1}$ to clayey soil did not increase the yield of miscanthus over four years in a temperate climate [27]. To determine the doses of fertilization in the experiment conducted, the fertilization requirements of miscanthus were taken into account: nitrogen (N)-90 kg.ha ${ }^{-1}$, phosphorus (P)-65 kg.ha ${ }^{-1}$, potassium (K) $150 \mathrm{~kg} \mathrm{ha}^{-1}$. Fertilization was adjusted to the soil volume contained in pots. When determining the doses of fertilization, the low $\mathrm{pH}$ value in the soil $\mathrm{KCl}$ (5.1) and the high $\mathrm{pH}$ value in the ashes from TUoMSS were taken into account (Table 2).

The $\mathrm{pH}$ of TUoMSS ash used in the laboratory experiments was 9.2. The content of phosphorus was $48.6 \mathrm{~g} / \mathrm{kg}$, potassium was $21.6 \mathrm{~g} / \mathrm{kg}$, calcium was $7.7 \mathrm{~g} / \mathrm{kg}$, and magnesium was $1.9 \mathrm{~g} / \mathrm{kg}$. The research showed that in the tested material, no nitrogen content was found, the value of which was below the limit of quantification, amounting to $1 \mathrm{~g} / \mathrm{kg}$.

The data obtained indicated that ash could be a good source of supplementing deficiencies, especially phosphorus and potassium in the soil. Such potential is also indicated by other authors. The condition for using the ashes for fertilization was to carry out the combustion process without additives (e.g., waste) increasing the calorific value, which load the obtained ash with pollutants [34,35].

An application of the ash from TUoMSS as a fertilizer fitted perfectly into the model of economy that promotes sustainable development and a closed resource cycle. This use was a good alternative for depositing waste in landfills. Agricultural management of biomass ashes could improve the soil and provide a source of nutrients for plants. Thus, biomass ashes could be substitutes for traditional fertilizers [36]. The potential indicating the use of ashes in agriculture was the content in their composition of significant amounts of potassium, phosphorus, calcium, magnesium, and numerous micronutrients. According to the research carried out by Piekarczyk et al., biomass ash also has a good effect on the physical properties of the soil; they also improve the abundance of available magnesium, potassium, and phosphorus [37]. They increase the sorption capacity of light soils and improve the air-water conditions of the soil. The reason for this beneficial effect is an increase in the soil particle size composition of dust and floated fractions [17]. For these reasons, the use of ash for soil fertilization, for the cultivation of plants for energy purposes, is motivated by measurable ecological and economic benefits. The condition for agricultural management of ash is to control the content of heavy metals that may lead to environmental contamination.

The search for alternative sources of biomass to be used in the energy sector increases the interest in the cultivation of high yielding crops. Kowalczyk-Juśko cites perennials, perennial grasses, shrubs, and trees as examples of plants with high yielding capacity [38]. The miscanthus is mentioned in the group of plants with a significant energy potential. The data show that its cultivation allows yields of 10 tons of dry matter (dry weight) per hectare. Higher yields are guaranteed only by sorghum, 49 tons of DM per hectare and Sakhalin knotweed 20 tons of dry weight per hectare. On the other hand, much lower dry matter yields are obtained from the crops of Jerusalem artichoke, willow, multiflower rose, prairie spartina, reed brain, poplar, alder, birch, and hazel, which have a yield ranging from 1.2 to 8 tons per hectare. An important advantage indicating the possibility of using miscanthus $x$ giganteus as an energy plant is its low nutritional requirements. 
The studies of Ercoli et al. and Iżewska show that miscanthus can be grown in extensive conditions, where it gives satisfactory crops $[39,40]$. Lewandowski et al. prove that this grass can be grown in soils of class IV, V, and even VI if the site is provided with an adequate amount of water [41]. The literature also indicates the potential of this species to strengthen erosive areas [42,43]. The high capacity of miscanthus in carbon sequestration was also noticed. According to many authors, the carbon sequestration process is very important in the cultivation of plants for energy purposes because it contributes to the reduction of greenhouse gas emissions $[44,45]$.

Carbon sequestration is a very important aspect of growing plants for energy purposes. The phenomenon of carbon sequestration in energy crops is based on the fact that, along with falling leaves and dying roots, the carbon assimilated in them goes to the soil and is used in cariogenic processes. The phenomenon of sequestration is of great importance in the carbon cycle, which has a direct impact on the balance of greenhouse gas emissions. According to Hansen et al., carbon sequestration at the level of $0.25 \mathrm{t} \cdot \mathrm{ha}^{-1}$ in multi-year cultivation of energy willow balances the balance of greenhouse gas emissions emitted during the combustion of biomass obtained from 1 ha of cultivation. In other studies, it was found that in energy willow cultivation, the carbon sequestration ranged from 0.55 to $0.83 \mathrm{t} \cdot \mathrm{ha}^{-1}$ and depended on the soil grain composition and age of the cultivated plants. According to the research by Hansen et al., the potential of miscanthus in the process of carbon sequestration was much higher and ranged from 0.78 to $1.13 \mathrm{t} \cdot \mathrm{ha}^{-1}$. This allows the tested species to be considered very efficient in the process of reducing $\mathrm{CO}_{2}$ emissions in the group of energy crops [44].

According to the source data, yielding is of key importance in the production of energy crops. Obtaining a large amount of biomass is a condition for production efficiency [46].

It was found that all the fertilization variants used had a positive effect on the height of the plants tested compared to the control group. By analyzing the effect of fertilization with ashes, it was found that the best effect on the height was obtained by applying the fertilization level of $8.32 \mathrm{~g}$ of ash. Plant height at this level of fertilization was on average $194.90 \mathrm{~cm}$. Similarly, when considering the effect of nitrogen fertilization, it was observed that the highest plants were obtained with a dose of $0.2 \mathrm{~g} /$ pot (the highest plants were $201.33 \mathrm{~cm}$ ). It is worth noting that fertilization only with ash from TUoMSS had a more positive effect on the height of the plants tested compared to the application of fertilization using only ash. The data analysis shows that the simultaneous application of nitrogen and ash fertilization had a beneficial effect on plant growth, with the tallest plants, $215.67 \mathrm{~cm}$ high, obtained with ash doses at the level of $8.32 \mathrm{~g} /$ pot and nitrogen at $0.1 \mathrm{~g} /$ pot (Table 4 ).

Further analysis of miscanthus biometric features showed that when fertilizing only with ash, the number of shoots in the pots ranged on average from 6.7 to 7.3 , but both at the level of 8.32 and 16.64, it was the same. The introduction of nitrogen fertilization improved this parameter. It is worth noting that the level of fertilization applied did not matter; the average spreading at the level of nitrogen fertilization of 0.1 and $0.2 \mathrm{~g}$ of nitrogen per pot were identical (Table 6). In the experiment carried out in the control pots, clumps spread to five to six stems. In pots with a dose of ash fertilization from TUoMSS $4.16 \mathrm{~g} \cdot \mathrm{pot}^{-1}$, the miscanthus propagation consisted of six to seven stems. In pots with a dose of ash fertilization from TUoMSS $8.32 \mathrm{~g} \cdot \mathrm{pot}^{-1}$, the miscanthus propagation consisted of seven to eight stems. In the pots in which at a dose $4.16 \mathrm{~g} \cdot \mathrm{pot}^{-1}$ of ashes the nitrogen fertilization at a dose of $4.16 \mathrm{~g} \cdot \mathrm{pot}^{-1}$ was applied, the propagation of miscanthus was 8.3 on average. In pots where, at the dose of $8.32 \mathrm{~g} \cdot \mathrm{pot}^{-1}$ ash, nitrogen fertilization was also applied at a dose of $0.1 \mathrm{~g} \cdot$ pot $^{-1}$, the propagation of miscanthus was 8.7 on average. A further increase of the nitrogen dose to $0.2 \mathrm{~g} \cdot \mathrm{pot}^{-1} \mathrm{did}$ not change the propagation of miscanthus. Increasing the dose of ash fertilization to $16.64 \mathrm{~g} \cdot \mathrm{pot}^{-1}$ also did not contribute to further increase of miscanthus propagation. The differences turned out to be statistically insignificant (Table 6). When comparing the own results with the research carried out in Germany, it was observed that the miscanthus yield in the second year of cultivation reached 10 tons of dry weight per hectare. In the following years of cultivation, the miscanthus yield 
increased significantly in the range from 20 to 30 tons of dry weight per hectare [33]. Other studies carried out in German conditions showed that the yield of miscanthus at the age of 4 to 9 years was from 14.8 even to 33.5 tons of dry weight per hectare. The long-term research of Kahle et al. on the cultivation of miscanthus on soils poor in nutrients proved that despite the lack of nitrogen fertilization, it was possible to obtain a miscanthus yield of 16 tons per hectare [47]. Jeżowski et al. state that the yield of miscanthus is mainly determined by the stage of plant development, as well as the diameter and propagation of the clump. The diameter of one-year-old miscanthus stems up to $1.5 \mathrm{~cm}$, while the clump's propagation in the first year amounts to an average of 15 stems. In the following years, the diameter of a one-year shoot reaches $2.5 \mathrm{~cm}$, while the number of shoots is 20 on average [42]. Ercoli et al., Clifton-Brown and Lewandowski show that the yield depends on the age of the plantation, harvest date, planting material used (rhizome, seedlings in vitro), position, fertilization, and ranges from 1 to 3 tons per hectare in the first year, i.e., in the year when the plantation was established, while the plants grow to $2 \mathrm{~m}$ in height. In the second year, the yield varies from 8 to 15 tons per DM and the plant height reaches $3 \mathrm{~m}$. From the third year, the plantation enters the period of maximum yielding, and the yields reach 25-30 tons of dry weight per hectare [21,39].

The field research carried out after the end of the experimental crops presented in this paper showed that in the first year of cultivation with the application of fertilization with the ash from TUoMSS municipal sewage sludge at the level of $3.7 \mathrm{t} \cdot \mathrm{ha}^{-1}$ and nitrogen at the level of $45 \mathrm{~kg} \cdot \mathrm{ha}^{-1}$, the average propagation of miscanthus was 9.3 stems per plant on average. In the second year, on the plots where fertilization with the ash from TUoMSS was applied at the level of $3.7 \mathrm{t} \cdot \mathrm{ha}^{-1}$ and nitrogen at the level of $45 \mathrm{~kg} \cdot \mathrm{ha}^{-1}$, the propagation of miscanthus plants was 20 stems on average.

Table 7 describes the calorific value of the aboveground miscanthus from the pot cultivation. The average calorific value of the miscanthus aboveground parts was $17.54 \mathrm{MJ} \cdot \mathrm{kg}^{-1}$. The fertilization with the ashes from TUoMSS did not significantly affect the changes in the calorific value of the above-ground parts of the plants tested.

The results of the calorific value in the studies conducted were slightly higher than the data published by [48]. These authors determined the calorific value of miscanthus biomass at the level of $16.48 \mathrm{MJ} \cdot \mathrm{kg}^{-1}$. For comparison, the energy value of other crops grown for energy purposes is: beech $20 \mathrm{MJ} \cdot \mathrm{kg}^{-1}$, cereal straw pellet $17 \mathrm{MJ} \cdot \mathrm{kg}^{-1}$, oat grain $16.6 \mathrm{MJ} \cdot \mathrm{kg}^{-1}[49,50]$.

Based on the observations made in the pot cultivation, the most favorable fertilization doses to be used in the continued field research were selected. The doses of ash fertilization from TUoMSS were selected for the field tests amounting to I- $0 \mathrm{~g} \cdot \mathrm{pot}^{-1}$, II $-4.16 \mathrm{~g} \cdot \mathrm{pot}^{-1}$, III-8.32 g. pot $^{-1}$. A further increase in the dose of ash fertilization to IV-16.64 g. pot $^{-1}$ in pot cultivation did not result in an increase in the yield. For the highest dose of ash fertilization, a decrease in the yield was recorded due to over-fertilization.

Using ash in the amount of $1.85 \mathrm{t} \cdot \mathrm{ha}^{-1}$, we provide $89.54 \mathrm{~kg} \mathrm{P} \cdot \mathrm{ha}^{-1}$ and $39.97 \mathrm{kgK} \cdot \mathrm{ha}^{-1}$. When using the dose of $3.7 \mathrm{t} \cdot \mathrm{ha}^{-1}, 179.08 \mathrm{~kg}$ of P.ha ${ }^{-1}$ and $79.94 \mathrm{~kg} \mathrm{~K} \cdot \mathrm{ha}^{-1}$ are put into the soil. However, the application of the dose of $7.4 \mathrm{t} \cdot \mathrm{ha}^{-1}$ puts $358.16 \mathrm{~kg}$ of P.ha ${ }^{-1}$ and $159.88 \mathrm{~kg}$ of $\mathrm{K} \cdot \mathrm{ha}^{-1}$ into the soil.

\section{Conclusions}

Miscanthus can be used as a plant with soil anti-erosion properties and soil strengthening; it has good soil improvement properties and a favorable carbon sequestration balance. Miscanthus does not pose a succession threat due to the way it reproduces in central Europe; hence, its cultivation may remain under control.

The research showed that the ashes from thermal utilization of municipal sewage sludge could be effectively used for the fertilization of miscanthus crops. In experimental crops, it was shown that the optimal level of miscanthus fertilization in terms of the yield was $8.32 \mathrm{~g}$ of ash per pot and $0.1 \mathrm{~g}$ of nitrogen per pot. As a result of laboratory tests, based on biometric features, the most favorable dose of ash and nitrogen fertilization from 
thermal utilization of municipal sewage sludge for use in field conditions was selected on the basis of biometric features, amounting to $3.7 \mathrm{t}$ ash $\cdot \mathrm{ha}^{-1}$ and $45 \mathrm{~kg}$ nitrogen $\cdot \mathrm{ha}^{-1}$. In order to reduce the costs of cultivation, it was possible to abandon the use of nitrogen fertilizers as their omission does not cause a significant drop in yield.

Author Contributions: Conceptualization, S.R. and K.T.; methodology, S.R. formal analysis, K.T.; writing-original draft preparation, S.R.; writing—review and editing, K.T.; All authors have read and agreed to the published version of the manuscript.

Funding: This research received no external funding.

Institutional Review Board Statement: Not applicable.

Informed Consent Statement: Not applicable.

Data Availability Statement: Not applicable.

Conflicts of Interest: The authors declare no conflict of interest.

\section{References}

1. Camilleri, M.A. The Circular Economy's Closed Loop and Product Service Systems for Sustainable Development: A Review and Appraisal. J. Sustain. Dev. 2018, 27, 1-17. [CrossRef]

2. Calzolari, T.; Genovese, A.; Brint, A. The adoption of circular economy practices in supply chains-An assessment of European Multi-National Enterprises. J. Clean. Prod. 2021, 312, 127616. [CrossRef]

3. Silvestri, F.; Spigarelli, F.; Tassinari, M. Regional development of Circular Economy in the European Union: A multidimensional analysis. J. Clean. Prod. 2020, 255, 120218. [CrossRef]

4. Harley, K.; Santen, R.; Kirchherr, J. Policies for transitioning towards a circular economy: Expectations from the European Union (EU). Resour. Conserv. Recycl. 2020, 155, 104634. [CrossRef]

5. Friant, M.C.; Vermeulen, W. Analysing European Union circular economy policies: Words versus sctions. Sustain. Prod. Consum. 2021, 27, 337-353. [CrossRef]

6. Fratini, C.F.; Georg, S.; Jorgensen, M.S. Exploring circular economy imaginaries in Europen cities: A research agenda for the governance of urban sustainability transitions. J. Clean. Prod. 2019, 228, 974-989. [CrossRef]

7. Bień, J.D.; Bień, B. Zagospodarowanie komunalnych osadów ściekowych metodami termicznymi w obliczu zakazu składowania po 1 stycznia 2016. Ecol. Eng. 2015, 45, 36-43.

8. Aleisa, E.; Alsulaili, A.; Almuzaini, T. Recirculating treated sewage sludge for agricultural use: Life cycle assessment for a circular economy. J. Waste Manag. 2021, 135, 79-89. [CrossRef]

9. Gherghel, A.; Teodosiu, C.; Gisi, S. Areview on wastewater sludge valorization and its challenges in the context of circular economy. J. Clean. Prod. 2019, 228, 244-263. [CrossRef]

10. Tsybina, A.; Wuensch, C.H. Analysis of sewage sludge thermal treatment methods in the context of circular economy. Detritus 2018, 2, 3-15. [CrossRef]

11. Kijo-Kleczkowska, A.; Środa, K.; Kosowska-Golachowska, M.; Musiał, T.; Wolski, K. Combustion of pelleted sewage sludge with reference to coal and biomass. Fuel 2016, 170, 141-160. [CrossRef]

12. Henclik, A.; Kulczycka, A.; Gorazda, K.; Wzorek, Z. Uwarunkowania gospodarki osadami ściekowymi w Polsce i Niemczech. Environ. Prot. Eng. 2014, 17, 185-197.

13. Burzała, B. Termiczne przekształcanie osadów ściekowych jako jedna z metod ich utylizacji. J. New Energy 2014, 1, 29-32.

14. Bień, J.D. Zagospodarowanie komunalnych osadów ściekowych metodami termicznymi. Environ. Prot. Eng. 2012, 15, 439-449. [CrossRef]

15. Białowiec, A.; Janczukowicz, W.; Krzemieniewski, M. Możliwości zagospodarowania popiołów po termicznym unieszkodliwianiu osadów ściekowych w aspekcie regulacji prawnych. Annu. Set Environ. Prot. 2009, 11, 959-971.

16. Stankowski, S.; Macirowski, R. Rolnicze wykorzystanie popiołów z biomasy. In Zagospodarowanie Ubocznych Produktów Spalania Biomasy; Seminarium Naukowe: Warszawa, Poland, 2011; pp. 159-180.

17. Biswas, B.K.; Inoue, K.; Harada, H.; Ohto, K.; Kawakita, H. Leaching of phosphorus from incinerated sewage sludge ash by means of acid extraction followed by adsorption on orange waste gel. Int. J. Environ. Sci. 2009, 21, 1753-1760. [CrossRef]

18. Guedes, P.; Couto, N.; Ottosen, L.M.; Ribeiro, A.B. Phosphorus recovery from sewage sludge ash through an electrodialytic process. J. Waste Manag. 2014, 34, 886-892. [CrossRef]

19. Pettersson, A.; Amand, L.E.; Steenari, B.M. Leaching of ashes from co-combustion of sewage sludge and wood-Part 1: Recovery of phosphorus. Biomass Bioenerg 2005, 32, 224-235. [CrossRef]

20. Stasta, P.; Boran, J.; Bebar, L.; Stehlik, P.; Oral, J. Thermal processing of sewage sludge. Appl. Therm. Eng. 2006, 26, 1420-1426. [CrossRef]

21. Clifton-Brown, J.C.; Lewandowski, I. Screening Miscanthus genotypes in field trials to optimize biomass yield and quality in Southern Germany. Eur. J. Agron. 2002, 16, 97-110. [CrossRef] 
22. Christian, D.G.; Poulton, P.R.; Riche, A.B.; Yates, N.E. The recovery of 15 N-labelled fertilizer appliee to Miscanthus x giganteus. Biomass Bioenergy 1997, 12, 4-21. [CrossRef]

23. Chae, W.B.; Hong, S.J.; Gi_ord, J.M.; Rayburn, A.L.; Widholm, J.M.; Juvik, J.A. Synthetic polyploid production of Miscanthus sacchariflorus, Miscanthus sinensis, and Miscanthus $\times$ giganteus. Glob. Chang. Biol. 2013, 5, 338-350. [CrossRef]

24. Baxter, X.C.; Darvell, L.I.; Jones, J.M.; Barraclough, T.; Yates, N.E.; Shield, I. Miscanthus combustion properties and variations with Miscanthus agronomy. Fuel 2014, 117, 851-869. [CrossRef]

25. PN-ISO 10390/1997 Jakość Gleby-Oznaczanie pH; Polish Committee for Standardization: Warsaw, Poland, 1997.

26. PN-R-04023:1996 Analiza Chemiczno-Rolnicza Gleby-Oznaczanie Zawartości Przyswajalnego Fosforu W Glebach Mineralnych; Polish Committee for Standardization: Warsaw, Poland, 1996.

27. PN-R-04022:1996+Azl:2004 Analiza Chemiczno-Rolnicza Gleby-Oznaczanie Zawartości Przyswajalnego Potasu W Glebach Mineralnych; Polish Committee for Standardization: Warsaw, Poland, 1996.

28. PN-R-04020:1994+Azl:2004 Analiza Chemiczno-Rolnicza Gleby-Oznaczanie Zawartości Przyswajalnego Magnezu; Polish Committee for Standardization: Warsaw, Poland, 1994.

29. PN-EN 14918:2010 Biopaliwa Stałe-Oznaczanie Wartości Opałowej; Polish Committee for Standardization: Warsaw, Poland, 2010.

30. Mocek, A. Gleboznawstwo, 2015; Polish Scientific Publishers PWN: Warsaw, Poland, 2015.

31. Kalembasa, D.; Malinowska, E. Zawartość potasu w różnych klonach trawy Miscanthus w zależności od nawożenia mineralnego. Fertil. Fertil. 2015, 3, 359-364.

32. Kalembasa, D.; Malinowska, E.; Jaremko, D.; Jeżowski, S. Wpływ nawożenia NPK na strukture plonu traw Miscanthus ssp. Bull. Plant Breed. Acclim. Inst. 2004, 234, 205-211.

33. Lewandowski, I.; Heinz, A. Delayed harvest of Miscanthus-influences on biomass quantity and quality and enviromental impacts of energy production. Eur. J. Agron. 2003, 19, 45-63. [CrossRef]

34. Ciesielczuk, T.; Kaszuba, G.; Nemś, A. Nawożenie popiołami z termicznego przekształcania biomasy źródłem pierwiastków śladowych dla gleb. Prot. Environ. Nat. Resour. 2011, 49, 219-227.

35. Krüger, O.; Christian, A. Recovery potential of German sewage sludge ash. Waste Manag. 2015, 45, 400-406. [CrossRef] [PubMed]

36. Jiménez, E.I.; García, V.P. Composting of domestic refuse and sewage sludge. I. Evolution of temperature, $\mathrm{pH}, \mathrm{C} / \mathrm{N}$ ratio and cation-exchange capacity. Resour. Conserv. Recycl. 1991, 6, 45-60. [CrossRef]

37. Meller, E.; Bilenda, E. Wpływ popiołów ze spalania biomasy na właściwości fizykochemiczne gleb lekkich. Energy Policy 2012, 15, 287-292.

38. Piekarczyk, M.; Kotwica, K.; Jaskulski, D. Wpływ stosowania popiołu ze słomy jęczmienia jarego na chemiczne właściwości gleby lekkiej. Fragm. Agron. 2011, 29, 127-135.

39. Kowalczyk-Juśko, A. Metodyka szacowania regionalnych zasobów biomasy na cele energetyczne. Zesz. Nauk. SGGW W Warszawie 2010, 85, 103-116.

40. Ercoli, L.; Matiotti, M.; Masoni, A.; Bonari, E. Effect of irrigation and nitro gen Fertilization on biomass field and efficiency of energy use in corp production of Miscanthus. Field Crops Res. 1999, 63, 3-11. [CrossRef]

41. Iżewska, A. Zawartość metali ciężkich w trzcinie chińskiej jako wskaźnik jej wykorzystania do utylizacji osadów ściekowych i kompostów z osadów ściekowych. Zesz. Probl. Postępów Nauk. Rol. 2006, 512, 165-171.

42. Lewandowski, I.; Clifton-Brown, J.; Trindade, L.M.; van der Linden, G.C.; Schwarz, K.-U.; Müller-Sämann, K.; Anisimov, A.; Chen, C.-L.; Dolstra, O.; Donnison, I.S.; et al. Progress on Optimizing Miscanthus Biomass Production for the European Bioeconomy: Results of the EU FP7 Project OPTIMISC. Front. Plant Sci. 2016, 7, 1620. [CrossRef]

43. Podleśny, J. Trawa Miscanthus x giganteus_-Jej charakterystyka oraz możliwości wykorzystania. Post. Nauk Rol. 2005, 2, 41-52.

44. Jeżowski, S.; Głowacka, K.; Bocianowski, J. Zmienność wybranych klonów traw olbrzymich z rodzaju Miscanthus pod względem plonowania w pierwszych latach uprawy. Zesz. Probl. Postępów Nauk. Rol. 2007, 517, 339-348.

45. Hansen King, J.A.; Bradley, R.I.; Harrion, R.; Carter, A.D. Carbon sequestration and saving potential associated with changes to the management of agricultural soils in Engeland. Soil Use Manag. 2004, 20, 394-402. [CrossRef]

46. Borzęcka-Walker, M. Symulacje plonu potencjalnego i sekwestracji węgla w glebie w uprawie miskanta. Fragm. Agron. 2006, 4, 195-202.

47. Lal, R. Soil carbon sequestration to mitigate climate change. Geoderma 2004, 123, 1-22. [CrossRef]

48. Kahle, P.; Beuch, S.; Boelcke, B.; Leinwebe, R.P.; Schulten, H.-R. Cropping of Miscanthus in Central Europe: Biomass production and influence on nutrients and soil organic matter. Eur. J. Agron. 2001, 15, 171-184. [CrossRef]

49. Komorowicz, M.; Wróblewska, H.; Pawłowski, J. Skład chemiczny i właściwości energetyczne biomasy z wybranych surowców odnawialnych. Environ. Prot. Nat. Resour. 2009, 40, 402-410.

50. Mółka, J.; Łapczyńska-Kordon, B. Właściwości energetyczne wybranych gatunków biomasy. J. Agric. Eng. 2011, 6, 141-147. 